報 文

\title{
パイライトを含む頁石の風化過程における 鉄, イオウおょひトレース金属元素の挙動
}

\author{
Research on the Behaviors of Iron, Sulfur and Trace Metals \\ During the Weathering Process of a Pyrite-Bearing Shale
}

村上定 瞭*吉 野 隆 ${ }^{*}$

A study on behaviors of iron, sulf ur and trace metals, such as cadmium, zinc and lead in the weathering process of pyrite-bearing shale and surface soil was conducted by observing the changes of their contents in the rock and soil under the oxidation conditions. The contents of iron, sulfur and lead in the soil were found to decrease, however, that of zinc to increase and taht of cadmium to remain unchange.

These results suggest that sulf ur is released from the rock as soluble sulf ate ion due to the dissolution of pyrite, and that irons are partly released as soluble ion( II ), but the rest remain in the soil as unsoluble ion oxides. The adsorptivity order of the tracs metals on/into the original and/or secondary minerals on weathering is zinc $>$ cadmium $>$ lead. The adsorptivity of trace metals seems to depend on the ionic radius of the metals, that is, the smaller radius, the more affinity of the metal to the minerals. However, behaviors of trace metals are too complicate to be explained only by the ionic radius.

\section{摘 要}

パイライトを含む頁石とての岩石が酸化的環境下で風化してできた土㙵中の鉄，イオウ，カドミウム，巠鉛拉よ び鉛の含有量を調へ，乙れらの化学元素の風化過程における動きを検討した，岩石と比較して，土壌中に掠ける各 元素の含有量は，鉄，イオウおよび鉛が減少し，特に鉛扔よびイオウの減少率が大きい，一方，亜鉛は増加してお り, カドミゥムはほぼ元の岩石中の含有量と同じであった.

イオウはパイライト溶出により硫酸根として離脱する．鉄は，一部鉄(II)イオンとして除かれるが，その大部分は 不溶性の酸化鉄として土壌中に留まるむのと思われる。風化過程に扔けるての岩石のトレース金属に対する吸着あ るいは保持力は, 亜鉛>カドミウム>鉛である. トレース金属元素の結晶イオン半径が小さいほど, その吸着力が 強いととが指摘される.しかし，鉱物の風化過程に扔いては多くの因子が作用し，イオン半径のみからてれらの金 属元素の挙動を説明することはできない.

*山1 大学工学部工業化学科 Sadaaki MURAKAMI and Takashi YOSHINO

Department of Industrial Chemstry, Faculty of Engineering, Yamaguchi University

0388-9459/82/0200-0386\$02.00/0 (C) 1982 Env. Cons. Eng. Assn. 


\section{ははじめに}

土壌中におけるカドミウムや亜鉛などのトレース金 属元素の挙動は, 環境污染の実態を解明する上におい て極めて重要で, 近年特に注目されている ${ }^{11}$. 一方, 土㙵は, 地殼を構成する岩石が長年月にわたって, 熱・ 風なよ゙の物理的作用や大気一水一岩石間の化学反応に よって破壊されたり，また岩石を構成する種々の鉱物 が 2 次変化して形成された大小さまざまな粒子に動植 物の遺体の分解物が混入しているあのである ${ }^{2)}$. した がって, 岩石の風化過程におけるトレース金属元素の 動きは, 鉱山の下流域におけるてれらの金属による土 袞污染機構の解明のみならず, 天然土壤中におけるこ れらの金属元素の挙動を解明する上においても, 重要 な知見を与えるものと考える. 各種の鉱物の風化過程 におけるケイ素やアルミニウムなどの主要化学元素の 挙動については, 古くから平衡論的観点から多くの研 究がなされ3-5), さらに, ここ十数年来, 速度論的研 究が注目されている6-9). しかし，カドミウムなどの トレース金属元素についての研究はほとんどなく, そ の風化過程に抢ける機構はよくわかっていない.

前回, 骨材用砕石と水との反応機構を, 主として水 の $\mathrm{pH}$ 変化より速度論的に調べた ${ }^{10)}$. 今回, 乙の岩石 を採鉱している工場において，岩層の堀削や砕石の際 生じた粉石が風化してできた工場内表層土を調査し, この岩石の風化過程における鉄, カドミウム, 亜鉛, 鉛およびイオウの各元素の挙動を検討したところ, 興 味ある知見が得られたので報告する．なお，採鉱され ている岩層は, 沿岸地域の海底で堆積・鉱物変化して できたもので，その大部分が頁岩よりなり，でく一部 が砂岩で構成されている11).乙の岩石の特徴としては, 一般に見られる堆積岩 ${ }^{12)}$ と比較して, カドミウムなど のトレース金属元素に関しては特に差異は認められな いが，パイライトの含有量が多いことである.

\section{2 調查項目および分析方法}

採鉱されている岩石および同工場内表層土について, それぞれ以下に示す分析方法により, 各項目を調查した。

\section{1 岩石}

岩石中の主要化学元素は, 試料を粉砕し, 純水で洗 浄・乾燥して, EPMA(Electron Probe Micro Analyzer）法により，その含有量を分析した。また，岩 石を構成する鉱物は顕微鏡観察およびX 線回折法によ り分析し，さらに主要三鉱物 (石英・長石・粘土鉱物)
の組成比は QXRD（Quantitative X-ray Determination) 法により求めた.

さらに, 鉄, カドミウム, 亜鉛, 鉛およびイオウの 各元素は, アルカリ $\left(\mathrm{Na}_{2} \mathrm{CO}_{3}, \mathrm{Na}_{2} \mathrm{O}_{2}\right)$ 融解, 酸 $(\mathrm{HCl}$, $\left.\mathrm{HNO}_{3}, \mathrm{HClO}_{4}\right)$ 分解およびフッ酸 $\left(\mathrm{HF}, \mathrm{H}_{2} \mathrm{SO}_{4}\right)$ 分解 の3 つの方法を使い分けて岩石を処理した後, JIS K 0102の各項目に準じて分析した。

\section{2 表 層 土}

農令24（昭 46.6.24)第 1 条 3 によって検体を作成し, 鉄, カドミウム, 亜鉛, 鉛およびイオウについて, 岩 石の場合と同じ方法により, それぞれの含有量を分析 した.

な技，今回，同岩層より涌出する水と岩石について 若干の実験を行なったが，乙の装置および方法につい ては, 前回報告した論文 $\left.{ }^{10}, 13,14\right)$ にその詳細が記載さ れているので省略する.

\section{3 結果}

\section{1 岩石}

本岩層の存在する地域は, 古代において遠浅の沿岸 地帯で, その後の地殼変動によって隆起してできたE 陵である.乙こで採鉱されている岩石は, 三畳紀に堆 積し,さらにこの堆積物が鉱物変化して形成されたも ので, 主として頁岩で, ごく一部が砂岩である ${ }^{111}$. ま た, 丘陵の切羽面にはいくつもの断層が見られ, 堆積 して形成された岩石の層が地殻の変動により, 複雑に 走向している. 頁岩と思われる岩石の主要化学元素の 一例を表 1 亿示す．また，乙の岩石に含まれる主要三 鉱物の組成比を表 2 亿示す. この岩石の特徵としては, 一般に見られる頁岩や砂岩 ${ }^{12)}$ などと比較して, イオウ の含有量が多いことである（一般に $\mathrm{SO}_{3}$ として $1 \%$ 以 下). このイオウの大部分は, パイライト $\mathrm{FeS}_{2}$ として含 まれている。乙れはおそらく，海水中に多量に存在す る硫酸イオン $(2700 \mathrm{ppm})$ がバクテリヤなどによる生 物学的還元や，さらに底質と海水との界面および底質 中に扔いて還元され, $\mathrm{FeS}_{2}$ として堆積したためと思わ れる（自然界に拈けるイオウの循環経路については, 多くの論文や成書がある. 特に, 海底の底質中への Fe $\mathrm{S}_{2}$ の濃集については, Trudinger らのすぐれた総説 ${ }^{151}$ がある). このことから, 岩層の割目より涌き出る地下 水に多量の鉄(II)および硫酸イオンが含まれている $\left(\mathrm{Fe}^{2+}\right.$, 20〜60 ppm ; $\mathrm{SO}_{4}^{2-}, 300 \sim 900 \mathrm{ppm}$ ).

一方, 乙の岩石と弱酸性の水を反応させると, 岩石 の陽イオン交換反応（この場合，可逆性抢よび不可逆 
表 1 岩石の主要化学成分

\begin{tabular}{crc}
\hline Constituent & Wt\% & Mole\% \\
\hline $\mathrm{Na}_{2} \mathrm{O}$ & 1.0 & 1.1 \\
$\mathrm{~K}_{2} \mathrm{O}$ & 1.8 & 1.3 \\
$\mathrm{MgO}$ & 3.2 & 5.5 \\
$\mathrm{CaO}$ & 4.4 & 5.5 \\
$\mathrm{Al}_{2} \mathrm{O}_{3}$ & 16.9 & 11.5 \\
$\mathrm{Fe}_{2} \mathrm{O}_{3}$ & 11.1 & 4.8 \\
$\mathrm{SiO}_{2}$ & 58.0 & 67.2 \\
$\mathrm{TiO}_{2}$ & 0.6 & 0.5 \\
$\mathrm{SO}_{3}$ & 2.9 & 2.5 \\
$\mathrm{Total}$ & 99.9 & \\
\hline
\end{tabular}

表 2 主要三鉱物組成比

\begin{tabular}{lc}
\hline Constituent & Wt\% \\
\hline Quartz & 12 \\
Feldspars & 19 \\
Clay minerals & 69 \\
Total & 100 \\
\hline
\end{tabular}

性の両方のイオン交換反応 $)^{101}$ によって $\mathrm{pH}$ は上昇し, 水はアルカリ性となる（この岩石を構成している各鉱 物之水との反応による $\mathrm{pH}$ 変化の定量的取扱いおよび

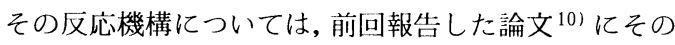
詳細が記載されているので, 省略する)。乙のことから， 涌水を放置して，乙れに含まれる鉄(II)が自然酸化して 黄色に懸濁したものとての岩石を酸素ガスを吹き込み ながら反応させると，一般に見られるパイライト溶出 16-18) による $\mathrm{pH}$ 低下は起らず, $\mathrm{pH}$ 上昇とと屯に涌 水中の未酸化の鉄(II)はすみやかに酸化 $\left.{ }^{19}, 20\right)$ されると ともに, 生じた水酸化鉄(III)は岩石表面に吸着される. 乙のとき, 鉄(II)の酸化速度は, 岩石中の鉱物の触媒作 用によって，かなり促進される。また，放置した際生 じた水酸化鉄(III)の沈殿も同時に吸着し, 黄色の䯚濁物 は白色化する。一方，パイライト溶出により，水相の 硫酸イオンは若干増加する。

岩石中のカドミウムなどのトレース金属元素は, 主 要化学元素と比較して, その含有量にかなりの変動が 見られた。乙れは，元の堆積層が形成したときの環境 条件が年代によって異なるためと思われる。特に，力 ドミゥムについて, その変動幅が大きく, $0 \sim 5 \mathrm{ppm}$ あった。しかし，大部分の岩石中のカドミウムは $0.1 〜$
表 3 岩石中の各化学元素含有量

\begin{tabular}{lrrrrrrr}
\hline \multirow{2}{*}{ Rock } & \multicolumn{2}{c}{$\mathrm{Fe}$} & & & $\mathrm{Cd}$ & $\mathrm{Zn}$ & $\mathrm{Pb}$ \\
\cline { 2 - 3 } \cline { 5 - 7 } & \multicolumn{2}{c}{$\%$} & & \multicolumn{3}{c}{$\mathrm{ppm}$} \\
\hline Shale A & 5.59 & 3.05 & & $<0.1$ & 27 & 4 \\
Shale B & 6.12 & 3.01 & & 0.4 & 24 & 15 \\
Sandstone & 5.31 & 2.27 & & 0.6 & 39 & 17 \\
\hline
\end{tabular}

表 4 表層土中の各化学元素含有量

\begin{tabular}{ccrrrrr}
\hline Sample & $\mathrm{Fe}$ & & $\mathrm{S}$ & $\mathrm{Cd}$ & $\mathrm{Zn}$ & $\mathrm{Pb}$ \\
\cline { 2 - 3 } \cline { 5 - 6 } No. & $\%$ & \multicolumn{4}{c}{$\mathrm{ppm}$} \\
\hline 1 & 4.73 & & 1,400 & $<0.1$ & 40 & $<1$ \\
2 & 4.72 & & 490 & $<0.1$ & 52 & $<1$ \\
3 & 3.47 & & 120 & 0.3 & 52 & $<1$ \\
4 & 3.39 & & 41 & 0.2 & 83 & $<1$ \\
5 & 2.70 & 20 & 0.3 & 104 & $<1$ \\
\hline
\end{tabular}

$1 \mathrm{ppm}$ 範囲内にあり, 一般に見られる頁岩や砂岩中 のもの21) ( $0.5 \mathrm{ppm})$ と同程度であった. カドミウム について, その含有量が平均的なものと思われる岩石 の分析例を表 3 に示す．乙の表の值に示すように，亜 鉛抢よび鉛の含有量についても，一般の堆積岩 ${ }^{21)}$ 亿見 られるもの（亜鉛, $80 \mathrm{ppm}$; 鉛, $20 \mathrm{ppm}$ ）と比較し て, 特に差異はないように思われる.

\section{2 表 層 土}

岩層の掘削や砕石により生じた粉石が風化してでき た工場内表層土の分析結果を表 4 亿示す. 試料の採取 場所は, その番号の大きいあのほど, 切羽斜面から水 平方向に遠くなっている（ただし, 植物が生育し, 表 層土の中に腐植質が混入していると思われる場所の試 料は除いた). したがって, 試料番号の大きいむのほど, 掘削・粉砕されてからの風化年月の長いものと考えら れる. 岩石之表層土之の分析値を比較すると, 興味あ る事実が 2,3 指摘される。 まず, 鉄, 鉛およびイオ ウの含有量が岩石と比較して, 表層土において減少し ており,さらに古い表層土ほど, 乙れらの含有量が低 い.イオウおよび鉛は, 特にその減少率が大きい.と てろが, 亜鉛は, 表層土に扔いて, その含有量が増加 しており,さらに古いものほど高い值を示している. カドミウムについては, 岩石と表層土に扔ける含有量 の差が小さく, また, 前述したように岩石中の含有量 の変動が大きく, 各々の表層土の元の岩石中の含有量 が不明であるため, 表 3 と 4 の值を直接比較すること は困難である. しかし, 岩石と表層土はほぼ同じ値を 示しており, また, 各表層土に扔いてはほぼ同じか, あるいは古いあのほど微増しているようにあ思われる。 


\section{4 考 察}

表層土中に打けるイオウの含有量は, 岩石と比較し て, その減少率が大きい。乙れは, 酸化的条件下の岩 石の風化過程で, パイライトが雨水や湧水などと反応 して ${ }^{17},{ }^{18}$ ) イオウが可溶性の硫酸イオンとして溶出し たからと思われる．イオウと比較して，鉄の減少率が 低いのは, パイライト溶出の際, 一部の鉄は可溶性の 鉄(II)イオンとして除かれるが，大部分の鉄は不溶性の 酸化鉄22,23) として, 土㙵中に留まるからと思われる. また, ケイ酸塩化合物中の鉄は, 風化の過程で変化し 形成される 2 次鉱物 ${ }^{31}$ の結晶格子内に保持されている からであろう。

一方，鉱物の風化過程におけるカドミウムなどのト レース金属元素の挙動に関する研究はほとんどなく， その機構についてはよくわかっていない。しかし，粘 土鉱物によるトレース金属元素の陽イオン交換反応に 関する研究は, 近年, 特に注目されている ${ }^{24-27)}$. たと えば，モンモリロナイトによる $\mathrm{Ca}-\mathrm{Cd}$ 抒よび $\mathrm{Ca}-\mathrm{Zn}$ の陽イオン交換平衡定数は ${ }^{27,28)}$, それぞれ $K\left(\mathrm{Kerr}^{29)}\right.$ の平衡定数 $)=0.49$ 㧍よび 0.97 で, 西鉛の方が大きい. これは，表層+のカドミウムおよび带鉛に対する吸着 力あるいは保持力と一致する。ささらに興味あることに は，鉛(II)，カドミウム(II) および要鉛(II)の結晶イオン半 径 ${ }^{30)}$ は， $1.24 ， 0.97$ 拈よび $0.71 \AA$ で, 乙の順序は表層 土中の含有量の減少率の順と一致している。このとと から，元来岩石に含まれている鉱物あるいは風化過程 で生じた 2 次鉱物のトレース金属イオンに対する保持 力あるいは吸着力の一つの因子として，イオン半径が 指摘される。

岩石の大部分を構成しているケイ酸塩鈗物の風化過 程に抢けるトレース金属元素の挙動に関して，つぎに 述べるような機構が考えられる。

1）岩石に元来含まれている鉱物や，さらに，てれら の鉱物が風化してできる 2 次鉱物の結晶格子内の金 属イオンと他の供給源からの陽イオンとの交換反応 (この場合, 粘土鉱物の層状構造間の金属イオンも 含む).

2 ）岩石の風化過程に打ける特定の金属イオンあるい は鉱物の選択的溶出.

3 ）風化過程で生じた無定形 2 次鉱物（コロイド状の 不溶物屯含む）内への金属イオンの取り込み.

4 ）他の供給源からの金属イオンの鉱物表面への吸着.

5 ）他の供給源からの金属イオンが加水分解・脱水反
応を行ない，コロイド状あるいは無定形の金属水酸 化物あるいは酸化物として鈗物表面に付着する.

1)，3）～ 5 ）のトレース金属元素の供給源として, 雨水や湧水に由来する地表水が挙げられる。 さらに， 硫化物として岩石に含まれているトレース金属（本岩 石の場合，パイライト中に $\mathrm{Fe}_{1-\mathrm{x}} \mathrm{Zn}_{\mathrm{x}} \mathrm{S}_{2}(\mathrm{x}<1)$ な どの形として含まれていると思われる）が，イオウの 酸化によりイオンとして遊離し，てれが供給源となる ことも考えられる。

ケイ酸塩鉱物構造内の陽イオンの配位席は酸素によっ て囲まれており，乙の陽イオンの安定化エネルギーに 対して, 酸素との静電的相互作用（結晶場理論）の寄 与が大きい311. したがって，1）打よび2）の観点から 考えれば，イオン半径の小さいイオンほど鉱物構造内 への吸着力あるいは保持力が大きいととが予想される。 これに反して，水と接している鉣物表面への金属イ才 ンの吸着については, そのイオン半径が小さいほよ゙, そのイオンの吸着力が弱いことか知られている。乙机 は，イオン半径が小さいほよ゙，逆に水和イオン半径が

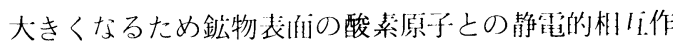
用が小さくなり，さらに衣南入吸隹する際の一部の水 和水の脱水利エネルギーが大きくなるためである ${ }^{31}$. したがって，4）の観点から考えれば，トレース金風の イオン半径が小さいほど，鈗物表而门の吸着力は将く なることが予想さ机る。金属の水酸化物については, 一般的傾后として，イオン半径が小さいほど加水分解 反応を起し，水酸化物を形成しやすい。しかし，金属 イオンと酸素（水酸イオン）との結合力に対するイオ ン性抢よび共有結合性の寄与が金属イオンによって異 なり,さらに水物化物沈期形成の際の凝集機構が複雑 であるため $\left.{ }^{3}, 13,23\right)$, 必ずしむ, 加水分解・水酸化物 形成とイオン半径との間に相関は認められない，たと えば，亜鈖，鈆抢よびカドミウムの加水分解斗衡定数231 はつぎのようであり，イオン半径の順と一致しない.

$$
\begin{aligned}
& \mathrm{M}^{2+}+2 \mathrm{H}_{2} \mathrm{O} \rightleftarrows \mathrm{M}(\mathrm{OH})_{2}(\mathrm{aq})+2 \mathrm{H}^{+} \\
& K=\frac{\left[\mathrm{M}(\mathrm{OH})_{2}\right]\left[\mathrm{H}^{+}\right]^{2}}{\left[\mathrm{M}^{2+}\right]}
\end{aligned}
$$

$\log K(\mathrm{I} \rightarrow 0): \mathrm{Zn}^{2+},-16.9 ; \mathrm{Cd}^{2+},-20.35$; $\mathrm{Pb}^{2+},-17.12$.

以上述べたケイ酸塩鉣物の風化過程におけるトレー ス金属イオンの挙動に関する議論は, 1)～5）の反応 機構が，それぞれ独立に進行した場合の極めて単純化 されたモデルについてのみ一元的に説明できるむので 
ある. しかし，実際には 1)〜 5 ) に加えて，さらに他 の反応機構が同時に, しかも相互に関係しあって風化 が進行する。また，一般の岩石や土壌の場合，乙れを 構成する鉱物の種類やその組成比がいろいろと異なる ため, 個々の岩石や土壌に対するトレース金属元素の 挙動は複雑であろう。さらに, 自然界に打ける岩石の 風化過程は, 後述するように種々の要因が作用するた め, 金属のイオン半径なよ゙の一要因のみで説明できる 屯のではない.つぎに，今回調査した表層土中への亜 鉛の濃縮であるが, これが鉱物の結晶構造内への取り 込みであるか, あるいはイオンまたは水酸化物之して 鉣物表面に付着しているのか, さらに供給源等に関し ては現在のところ不明であり, 今後の検討が必要であ る. なお, この㞸不の洗浄水の水処理施設に打ける水 質执よび底質中の鉄, イオウおよびトレース金属元素 の挙動については, 近くその詳細を発表する予定であ る. 水質については, 曹鉛およびカドミウムが咸少し, 鉊は增加しているが，逆に底質中においては，要鉛扔 よびカドミウムが濃縮され（濃縮率は亜鉛の方が大き い), 鉛は減少している. 特に, 底質ゆへのトレース金 属元素の濃縮率が表煟土中のものと似かよっている点 が注月される。

\section{5 おわりに}

今回調查した岩不の風化過程におけるカドミウムな よ゙の化”学元秦の挙動は, 酸化的条件下に加えて, 有機 化合物なよ゙の存在しない化学環境下におけるものであ る.しかし, 自然界においては, 酸化環元, 生物や種々 の有機・無機化合物が，いろいろな形で岩石に作用 するため, 一般の岩石の風化過程は極めて複雑で, そ の化学的・生物学的環境の差異によって, 各元素の挙 動はいろいろと異なるであろう。たとえば, アミノ酸 やポリアミノ酸化合物のトレース金属イオンに対する 親和力は, 一般に鉛 (II) > 要鉛 (II) > カドミウム(II)で 32,33), 今回調查した表層土中の鉱物に対する吸着力 とは異なる。アミノ酸なよ゙の有機化合物に対する親和 力は, イオン性および共有結合性の相互作用の他に, 金属イオンの配位構造や錯体を形成する際の脱水和工 ネルギーが作用する ${ }^{34,35)}$ 。さらに, 銅(II)などの遷移金 属イオンの場合, 配位場安定化エネルギーが加わる ${ }^{35}$, 36). また, 酸化遷元電位の変化に伴なう硫酸一硫化物 系の反応によるトレース金属元素の土壌中への蓄積や 土壌加の溶出機構については, よく知られている1,15). 以上のことから, 一般の腐植質を含む土袞中のト
レース金属元素の含有量は, 今回調查した表層土中の ものと比べると, かなり異なっている. 今後, 環境科 学, 特に鉱山などの下流域におけるトレース金属元素に よる土壤污染の機構を解明する上において, 種々の条件 下の岩石の風化過程における各化学元素の動きに関す る研究が重要であると考える.

\section{参考文献}

1) 飯村康二; 土壌污染の機構と解析一環境科学特論一, 渋 谷政夫編, 産業図書 (1979), 7 章.

2 ) D. N. Lapedes, Ed.; "Encyclopedia of the Geological Sciences, " McGraw-Hill, New York (1978), p. 765.

3 ) W. Stumm, J. J. Morgan; “Aquatic Chemistry-An Introduction Emphasizing Chemical Equilibria in Natural Waters," Wiley, New York (1981), 2nd Ed., Chaps. 9 and 10 .

4) M. L. Jackson; Soil Sci., 16,3 (1948).

5) D. H. Yaalen;J. Chem. Educ. 36, 73 (1952).

6) R. Wollast; Geochim. Cosmochim. Acta, 31, 635 (1967)

7 ) R. W. Luce, R. W. Bartlett, G. A. Parks; Geochim. Cosmochim. Acta, 36, 35 (1972).

8 ) H. C. Helgeson; Geochim. Cosmochim. Actu,35 , 421 (1971).

$9)$ G. R. Holdren, Jr., R. A. Berner; Geochim. Cosmochim. Acta, 43, 1161 (1979).

10）村上定䀥，占野 隆；噮境技術，11，883（1981）.

11）村上定瞭；地澌調查報告書（1980）.

12) F. J. Pettijohn; "Sedimentary Rock," Harper \& Row, New York (1975), 3rd Ed., Chap. 8.

13) T. Yoshino, S. Murakami, H. Takesue, A. Ito; J. Inorg. Nucl. Chem., 41, 1015 (1979).

14）村上定䝤，松崎浩闰，吉野隆；水処理技術，21，123 (1980).

$15)$ P. A. Trudinger, D. J. Swaine, Ed.; "Studies in Environmental Science 3 - Biogeochemical Cycling of Mineral-Forming Elements,“ Elsevier, Amsterdam(1979), Chap. 6

16) R. M. Garrels and M.W. Thompson; Amer. J. Sci., 258, A5 7 (1960).

17) Reference 3, p. 469.

18) K. L. Temple, E. W. Delchamps ; Appl. Microbiol., 1 ,255 (1953).

19) W. Stumm, G. F. Lee ; Ind. Eng. Chem., 53, 143 (1961).

$20)$ H. Tamura, K. Goto, M. Nagayama ; J. Inorg. Nucl. Chem., 38,113 (1976).

21) D. A. Andrew-Jones; Mineral. Ind. Bull., 11, 1, (1968).

22) A. F. Cotton, G. Wilkinson; "Advanced Inorganic Chemistry,” Wiley, New York (1972), 3rd Ed., p. 836.

23 ) C. F. Bates, Jr., R. E. Mesmer; "The Hydrolysis of Cations," Wiley, New York (1976), 2nd. Ed., p. 226.

24) M. H. El-Sayed, R. G. Burau, K. L .Babcock; Soil. Sci. Soc. Am. Proc., 34,397 (1970).

25) J. V. Lagerwerff, D. L. Brower ; Soil. Sci. Soc. Am. Proc., 36,734 (1972)

26) M. B. McBride; Soil. Sci. Soc. Am. Proc., 40,452 (1976). 
27）飯村康二; 近代農業における土軖肥料の研究, 養賢堂 (1973)，第 4 集, p. 46.

28）飯村康二, 伊藤秀文; 土肥誌, 49，95（1978）.

29) H. W. Kerr ; Soil. Sci., 26, 384 (1928).

30）日本化学会編; 化学便覧 基礎編II, 丸善（1966）, p. 1264.

31) R. G. Burns ; "Mineralogical Applications of Crystal Field Theory," Cambridge, Cambridge Univ. Press (1970), Chap. 1 .

32) J. Lewis, R.G. Wilkins, Ed .; "Modern Coordination Chemistry - Principle and Method," Wiley, New York (1960), Chap. 1 .

33) S. Murakami ; J. Inorg. Nucl. Chem., 43, 335 (1981).

34) G. H. Nancollas; Coord. Chem. Rev., 5,379 (1981).

$35)$ S. Murakami, T. Yoshino; J. Inorg. Nucl. Chem., 43, 2065, (1981).

36) A. E. Martell, Ed.; "Coordination Chemistry," Van Nostrand Reinhold, New York (1971), Vol. I, Chap. 8 .

（受付 S 56. 5. 27)

\section{主 な 既 刊 書}

下水·廃水·污泥処理ガイドブック

〈著者〉松本順一郎外 32 名

A 5 判 1250 頁, 定価13,000円

\section{し 尿処理ガイドブック}

〈著者〉岩井重久 外50名

A 5 判 760 頁, 定価 9,000円

\section{生活系排水処理ガイドブック}

〈著者〉洞沢勇外22名 A 5 判 480 頁, 定価 8,500円

\section{下 水道必携 \\ 〈著者〉野中徹一外 24 名 \\ B 5 判 650 頁, 定価 7,500 円}

\section{悪 臭 防 止技術要 覧}

〈編著者〉西田耕之助 不黑 唇吉

B 5 判 330頁，定価 3,300円

\section{污 泥研 究 年 報'81}

〈著者〉川鼠普外25名 B 5 判 500 頁, 定価 6,000円

\section{公害防止のための計測機器概説}

〈編著者〉柳沃三郎外 8 名 B 5 判 240 頁, 定価 2,800円

\section{わかり易い公害分析計測基碟講座}

〈著者〉日色和夫 外 5 名 B 5 判 113 頁, 定価 1,800 円

\section{廃棄物処理技術総集編}

〈編著者〉吉田総夫

B 5 判 258頁，定価 4,200円

-申込み・問合わせ先

\section{環境技術研究会 図書係宛}

昰550大服书西区京町䖯1-14-25(京二ビル)

8 (06) $443-6445 \cdot 9027$ 